\section{Globalization and the de-Anglicization of English}

\section{Gillian Perrett}

Universiti Brunei Darussalam

\begin{abstract}
With the development of globalization cultural issues associated with TEFL are inevitably being transformed. In the modern world peoples were grouped within nations and communicated in speech communities largely within their own countries; communication outside the boundaries of the national speech community was not the norm for the majority of people. In the post-modern world the position of these vertica boundaries is changing to horizontal and an upper stratum of society (wherever it is located) is able, with computer technology, to communicate relatively freely across national boarders. The lingua franca of this communication is English. It is not the English of any particular country and it is developing new cultural norms, especially in the electronic media. In one stratum professional functions dominate and electronic usage closely reflects familiar print genres. In other strata more interpersonal functions occur and at the same time the language is moving away from old standard forms; this is most apparent in email and chat room discourse. Teachers have to shift from traditional notions of culture and situation and embrace the new electronic forms, finding ways to help their students participate fully in the new intercultural situation.
\end{abstract}

Key words: globalization, de-Anglicization.

Globalization has not been universally welcomed. Speaking in Singapore eight years ago one icon of British TEFL, Alan Maley, told his audience, "Culture-death is imminent. A global, leveling, lowest common denominator culture, crass and trivial, is in the process of engulfing all our local cultures, in all their rich variety, in just the same way it took over in the USA three decades ago" (1996:5).

He blamed consumerism, globalization, electronic media and the resultant trivialization. Six years later Goenawan Mohamad complained to another conference in Singapore that local languages suffer as a result of the spread of English

"Our language has been ripped from the world, stripped of shape, smell, colour and form, cleansed of the grit and grafitti, the rumpus and commotion that make up real life" (IPS, 2004).

Robert Phillipson put these concerns into perspective when he recently reminded readers, "the vast majority of the world's citizens don't even know English, whether as a mother tongue or a second or foreign language" (2001:1). Nevertheless at that recent Singapore conference on language trends in Asia two major speakers acknowledged the importance of globalization for ELT. Dr Rjaya Abhakorn (Chiang Mai University) observed:

"In South East Asia, the response to globalization is to acquire language skills, not in many languages, but in one, the English language, which is seen as the key to success in the globalised age" (IPS, 2004).

Prof Jo Lo Bianco (NLLIA, Australia) emphasized the inevitability of homogenization:

"Globalised modernization requires that knowledge is imparted in ways that are comparable across differences of setting, culture and language" (IPS, 2004).

Abhakorn's and Lo Bianco's words remind us that whatever pressures are put on traditional cultures and local languages, English offers an instrumentality that is going to be used by those who have access (or seek access) to the globalized world.

In the context of thinking about TEFL and the teaching of culture, this paper will look at the gradual spread of the English language across the globe. The positions of English in the modern and postmodern worlds will be compared and suggestions made for how the TEFL profession can adjust 
to these changes. Firstly it will contextualize the discussion by dealing with key terms: culture, then globalization, the spread of English, modernity and post-modernity. It will then focus on that new arena for the globalized use of English, computer-mediated communication, and consider newly developing language norms. This will lay a platform for suggesting some implications for TEFL teachers in SE Asia.

\section{CULTURE}

The concept of culture has a long history. Matthew Arnold's view of culture as "contact with the best which has been thought and said in the world" (1869) is the one that used to inform language teaching, with teachers wenerally seeing their aim as being to prepare students for the study of literagenerally seeing their aim as being to prepare students for the study of ture which expresses that "best". But in 1957 culture in terms of daily life and values. His work gives substance to Geertz's statement:

"The concept of culture I espouse. . . is essentially a semiotic one. Believing, with Max Weber, that man is an animal suspended in Believing, with webs of significance he himself has spun, I take webs, and the analysis of it to be therefore not an experimental science in search of law but an interpretative one in search of meaning" (1973:4-5).

A more concise definition of culture is, "Culture consists of the patbehaviour (both mental and physical) that individuals learn and are taught as members of groups" (Hunter \&Whitten, 1977:28)

Modern definitions of culture point to two things: culture is about peole in daily life and cultures change and develop. For anthropologists, culture is about social organization and systems of values and beliefs. For linthe engage in society language must be used and that guists the point is that to engage in society language mis language and culture language is thus a semiotic system (Halliday, 1978). As language and

are inextricably combined, when they change they change together.

I have sometimes asked teachers to consider whether they prefer to think of culture as an integral part of communicative competence, or of it being a separate block in the language curriculum. Of course, in framing the question in this way I am oversimplifying it, and of course teachers tell me this. In fact, what can be said about culture takes many points of view; but the debate about teaching culture can be encapsulated in three clear positions.

1. It used to be considered that conveying high culture was the real aim of language teaching so language-focused lessons were seen as introductory. Liddicoat and Crozet refer to this point of view, without endorsing it, thus:

Traditionally, in language-based subjects, whether they be first or second languages, the work of teaching culture has been seen to be a part of the work of teaching literature. In particular language students were expected to eventually gain an introduction into the canon of literary works valued in the particular society in which the language was spoken. This particular approach to culture starts with the materials produced by that culture and defines culture as the valued artifacts of a particular society" (1997:1).

2. The second is that language is essentially a vehicle of communication and therefore it can be taught with or without culture, according to either the teacher's decision or national educational policy. In this view it is possible to teach information about the way of life of English speaking people separately from teaching English as a means of communication. When culture is taught using this approach it is sometimes referred to as teaching cultural literacy. Thus "culture is often seen as mere information conveyed by the language, not as a feature of language itself; cultural awareness becomes an educational objective in itself, separate from language" (Kramsch, 1993:8).

3. A different view is that we cannot avoid teaching culture, even if we would, because language is an expression of the culture in which it is embedded, "the "whole way of life" of a social group ... - texts, images, talk, codes of behaviour, and the narrative structures organising these which shape every aspect of social life". (Frow and Morris, 1993; cited by Lee and Poynton, 2000:7) "If however, language is seen as social practice culture becomes the very core of language teaching. Cultural awareness must then be viewed both as enabling language proficiency and as being the outcome of reflection on language proficiency" (Kramsch, 1993:8). 
If language teachers accept that language and culture cannot be separated then they surely have to worry about the effects of the teaching of language on the balance between different cultures in the world. The phrase "cultural imperialism", first coined in the 1970s (White, 2000) became a vogue word by the 1990s according to Taylor (2004), who defined it as " an imbalance in the flow of information from the First World to the Third World." The very phrase "cultural imperialism", like the derived phrase "linguistic imperialism" (Phillipson, 1992) implies criticism of a powerful and unwelcome force. However, Garofalo finds a number of weaknesses with the concept of cultural imperialism. He thinks - quite rightly - that the outside forces are not so strong and that existing local cultures are quite able to resist them. He thinks that economic power does not always have cultural effects; he observes that "receiving" populations are not always passive or lacking in creativity (1993:18). Those of us who are involved with furthering the spread of global English must hope that he is correct; indeed it may be that the further the language spreads the less it can do the bidding of any one particular group of native speakers.

\section{GLOBALIZATION}

The term globalization is recorded as being first used in 1962 (Oxford English Dictionary). By the end of the century it was the major buzzword. One web site claims, "One can be sure that virtually every one of the 2822 academic papers on globalization written in 1998 included its own definition" (Globalization Guide.org, 2002). Many see it as a primarily economic phenomenon which involves the integration of national economic systems through the growth in international trade and investment. Stromquist (2002) notes that besides this economic globalization there is technological globalization (within which she includes the "recent information revolution" and increased international social and cultural exchange: "As others, we recognize that the intense and constant movement of goods, jobs, and capital that constitutes globalization creates political, environmental, and cultural consequences" (p.3).
Who or what is the driving agency is a political question: to what extent is the process driven by national governments, and to what extent is the power of the nation state being taken over by the multinational corporations who fund them? Some might say it is a process which has gathered such momentum that it is not possible to find clear agency or responsibility at all

Globalization is often conceived in terms of the notion of centre and pe. riphery, a notion applied by political scientists to study relations both within countries and among countries. The term originated in critiques of colonia systems: "Soros ... divides the "global capitalist system" into a centre (US, Western Europe, Japan) and a periphery (Asia, Latin America, Russia, East Europe, Africa). Under this system capital flows from the centre to the pe riphery and back, supposedly to the mutual benefit of both." (A.L.B., 1999) This same notion of centre and periphery is familiar in Applied Linguistics due to Kachru using it to discuss the spread of English (see below).

\section{THE SPREAD OF ENGLISH}

For globalization to happen there does, of course, have to be a common medium of communication, a common language. That this language has turned out to be English is no random matter: there are clear historical reasons.

The phrase "English as a world language" was current in the TESOL community before the word "globalization" pushed to the forefront. Study ing the history of the English language involves learning about how one tiny local dialect from southwest England spread to southeast England and then around the world. To use a metaphor: we can think of the English language as a body of water, which commenced its life as a small puddle in one part of southern England. It grew into a lake large enough to encompass first the whole of England and then the British Isles. It continued to grow and formed rivers; the first ran to the United States, others to Australia, South Africa and so on. This spread was assisted by $19^{\text {th }}$ century imperialism, and so, with the break up of the British Empire in the middle of the $20^{\text {th }}$ century, a contraction was anticipated. (For example the Dutch language has not survived in Indonesia, nor is French anything more than a cultural relic in Vietnam.) This anticipated contraction did not occur for three reasons. There was the resilience of some of the institutions left in former colonies. Consider for instance the British-based legal system in India: at Independence it was recog- 
nized that English would be required in the short term to maintain the continuance of government and legal work and it was declared a national language for the first fifteen years only; yet it has never proved possible to phase it out. The dominance of English is also due to the military and commercial ascendancy achieved by the United States during the second half of the $20^{\text {th }}$ century and the development of the globalized world economic system mentioned above. English seems quite well established, at least for the time being.

The English language had always traveled and the river has found new courses, but now it has burst its banks the trickle, that became a flow, has become a deluge. This has adjusted the relationship between language and culture. When it traveled slowly new and distinctive cultures developed. The different national varieties of English express different national cultures just as they show differences in pronunciation in America, the Caribbean and New Zealand, for example. Now, as English has more second language speakers than first language speakers (Graddol, 1997:2) the water is spreading much more thinly. For teachers who understand the links between language and culture this may seem a confusing situation: a world language that is losing its connections to specific cultures. This is the difference betweeri the position of English in the modern world and English in the post-modern world.

\section{English in the Modern World}

The modern attitude (which developed during the nineteenth century) was one of certainty, a trust in rationality and in the physical laws of science. The development of nation states contributed to the idea of progress. Peoples were grouped within nations and communicated principally within the speech communities within their own countries; communication outside the boundaries of the nation and the speech communities it contained was not the norm for the majority of people. This is not to say that there were no horizontal boundaries within states; class distinctions, reflected in language use certainly existed. But the modern world was divided principally by vertical boundaries, boundaries which identified national languages as belonging to nation states. As new nations sprang into existence it made sense to legislate national languages into legal status.
In response to these modern developments, applied linguists took over the centre periphery concept from cultural anthropology. Countries at the centre were those with native speaker varieties of English. Holliday (1994a, 1994b) calls these the BANA countries because they include Britain, Australia and North America. The periphery refers to all other national varieties of English spoken in the world. Kachru (1988) divided the periphery varieties of English into two groups: the outer (or extended) circle and the extending circle (Figure 1). The outer circle referred to countries where English is used as a one of a group of first languages or as a second language, for example Singapore, Malaysia and India. The extending circle refers to countries which use English as a foreign language, such as Japan and Indonesia.

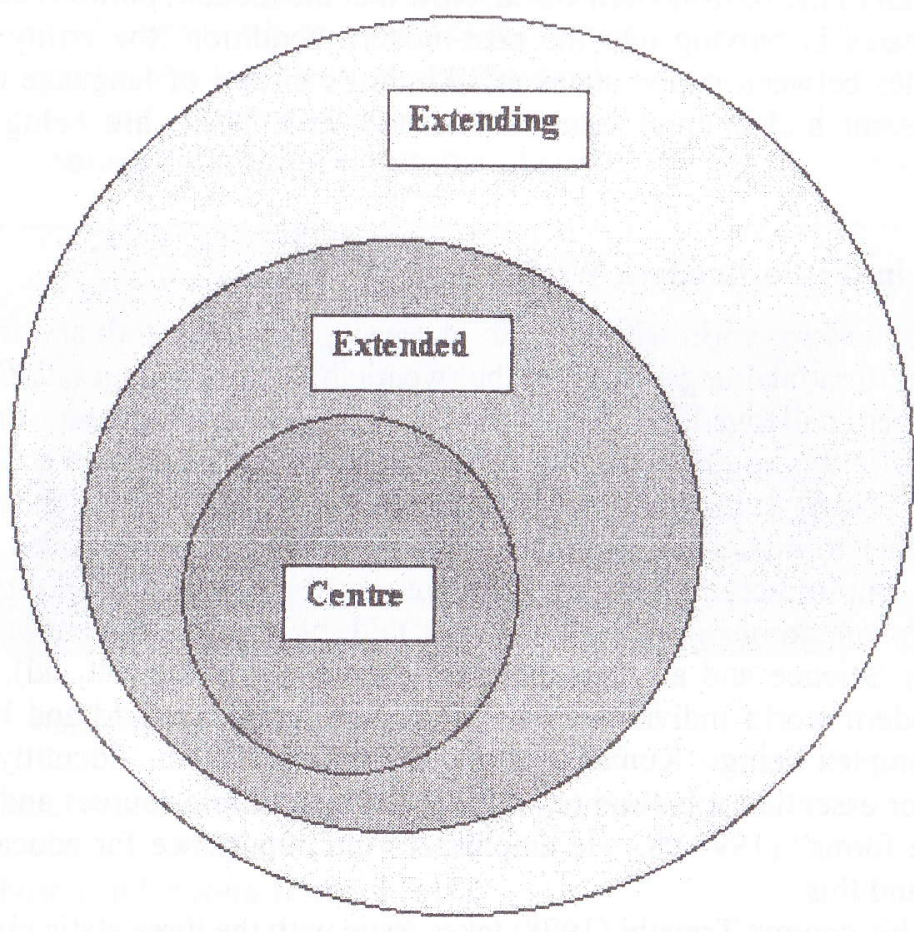

Figure 1: Kachru's Concentric Model (1988) 
Yamaguchi (2002) argues that English as an International Language belongs in the expanding circle. She claims, "it is often said that non-native speakers use English more as a lingua franca between themselves than in enspeakers use English more as a lingua franca between the property of its native speakers". If she were correct EFL speakers would communicate principally speakers". If she were correct EFL speakers would communicate principally with other EFL speakers. This is patently not the case. Her argument deemphasizes the fact of lingua franca use across circles and is very much a modern view.

In my view it is time to stop referring to ESL and EFL countries and to confine these terms to individuals: the circumstances in which a person is These distinctionstances in which a person is learning or using English. These distinctions applied better to the modern world than to the post-modern world. Now that the modern political world of world than to the post-modern world. Now the nation states is move are less relevant and cultural issues associated with TEFL are being transformed.

\section{English in the Postmodern World}

The modern world with its faith in reason, progress, truth and facts received its first challenges early in the twentieth century (Klages, 2003) and was further challenged by the post World War Two development of relativwas further challenged by the post wore is no single truth, that there are different ways of looking at the same thing. (Michel Foucault (1972) was the leading pilosor the thing of society is not based on obphilosopher to demonstrate that the facts.) Postmodernism involves a loss of faith by many in the answers provided by Science and all "big theories" (Sociology at Hewett, nd). In the post-modern world individuals live in a more complex world and become more complex beings. Kumar says that in postmodernism, "identitiy is not unitary or essential, it is fluid or shifting, fed by multiple sources and taking multiple forms" (1997:98). He emphasizes the importance for educators to understand this.

In this context Tripathi (1998) takes issue with the three static circles of Kachru's model. Among the points he makes is that there are greater differ(an within individual countries than between countries in different circles (p.56). He points to migra- tions patterns in the globalized world as being responsible for this. There is also the development of global communication systems; in the post-modern world a person is able, with education and access to computer technology, to communicate freely across national borders.

I suggest a more fluid model (Figure 2). In the vertical strips countries are located in vertical bands, tall bands where most language use is not English and short bands where there is a great deal of English use. The horizontal layer at the top is filled by people in any of (ultimately all) the countries of the world who use English to communicate with each other. The English that these people use is not the English of any particular country. Further, it is developing its own culture and subcultures. In some registers it mixes freely with other languages. It is less and less driven from the centre. It is moving out of a space where it defines the identity or history of a nation, or where it can be legislated as part of a political process. It is moving freely across the world. Communications satellites and the use of internet and email technology are making a tremendous contribution to this process.

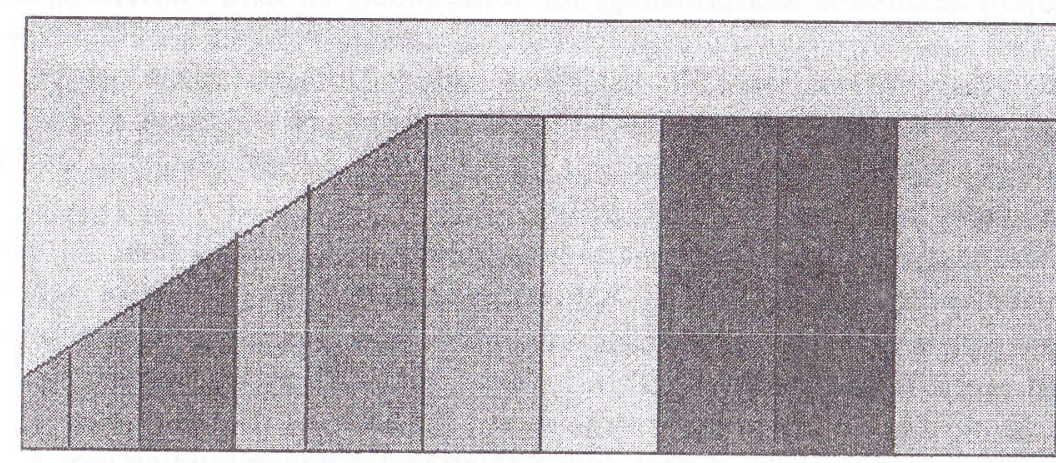

Figure 2: Suggested Horizontal Model

Where does this new English belong? Everywhere.

Whose is it? Noone's; everyone's. 
Speakers are changed by the languages they speak; languages are Sy the usefulness of English that overcomes local hostility, it is also the awareness that the language is being freed from the control of the British or the Americans, and that any groups of local users can influence its development.

\section{Newly developing norms}

Applied linguists have been writing about new norms for decades. It took a while for the new post-colonial varieties of the modern era to become accepted. Note that seminars on Indian English were being held in the 1982.148) but the Oxford University Press only published its (Australian) in 1989 and it still has no (Global English, n.d.). The question asked by "which variety of English should English language teachers has shifted from, "which variety of English should be taught British or American?" to "which varieties will our to use?" The answer was probably, for some time, "British, American and SE Asian English - they must at least have a receptive command of those " "International Fnglish" was included. Its relevance has been . priety or group of varieties: e-language, e-speak, or what David Crystal calls "netspeak" (Crystal, 2001).

Illeducated classes; these people increasingly looking outside national boundaries for both information are increasingly looking area accessible to and interaction. Computer-mediated communication is an area accessible to the haves and not accessible to the have-nots. This matter of accessibility reinforces old barriers between privilege and the lack of it and creates new ones. This concept of the digital divide (National Telecommunications and Information Administration, 1999) is a matter of social justice which must not be ignored. But as a metaphor the "digital divide" is too simple. It suggests there simply two groups, those with and those without access to computers, but as Cisler (2000) pointed out there are many different levels of ac(2003) adds, it is not the existence of the internet come from the "political, ecothe disparities; they come from the "political, economic institutional, cultural, and linguistics contexts that shape the meaning of the Internet in people's lives" (p.297).
When we log onto the internet we encounter new groupings of people, new genres of discourse and new styles of writing, with English being the predominant language of the net. When our students use the internet they may be dealing with people they know face to face or those whom they do not. They may email fellow students or they may reach out across the globe. Applying this concept to educational sites we can see two main models. Some lecturers use the net to add value to conventional face-to-face teaching by putting lecture notes or a reading list on a web page or setting up a discussion group. Some courses are taught entirely on-line, with a homepage holding together a whole program of on-line study and fellow students never meeting each other face-to-face.

Crystal (2001) describes five types of internet-using situations: web pages, email, discussion groups, chat rooms and virtual worlds (2001:10-13). When he coins the term "netspeak" (p.17) for the language used there he points out that it combines features which traditionally are associated with writing only or speech only. Coghlan (2001) quotes the student who said of email, "Is this writing or talking?" This alerts us to look for new genres, to new modes of cultural expression.

The "most written" e-texts appear as web pages. Many documents originally designed for paper publication are deposited here. It is now possible to consult university handbooks and academic journals both online and in conventional printed form. Some articles written in academic style are published only on the web, but in all these cases they look like print media; traditional academic reading skills remain all that are needed to deal with them once they have been located. Whilst Google and Yahoo are extremely userfriendly, database search skills are needed for searching library and other databases online.

Most homepages, however, are quite different from print media, even from magazine pages (although these too use graphics, multicolumn layouts, and varied uses of script and graphology). Homepages typically contain short "grabs" of text with links to further information and their layout encourages the development of new patterns of eye movements. The glance has to be exploratory in all directions rather than rely on the left to right, top to bottom sweeps appropriate for reading print media. This means that for our students to develop e-literacy they must become able to deal with new graphic and graphological features in addition to the grammatical, lexical, and discourse features of language. Crystal (2001:7) notes that, because 
websites can use sound files as well, familiarity with the phonetic and phonological features of spoken language is also required. The www is "elaborately structure ... graphically rich" (Crystal, 2001:43).

Like printed pages, web pages do not require direct responses from readers. In contrast, the other internet situations he mentions do. They are transient like speech, but slower than speech (Crystal, 2003:29-30). The speed of the responses required varies in different internet situations.

In this situation where new conventions are being created at incredible speed teachers must use descriptive linguistic responses rather than prescriptive ones (Crystal, 2003:63) and generalities may well prove correct only temporarily. Nevertheless I will now describe characteristics of two particular internet situations: emails and chat rooms.

The structural elements of e-mails have become fixed; mail programs provide fields for addressee, addresser, recipients of copies, subject line, and generate date, time, and automatic signature. Only the contents of the message field is left to the choice of the writer, and writers use a variety of different genres in this field. From my personal inbox I provide examples of a formal letter, a professional memo, a personal letter, a casual note, and a pair of brief, sms-style messages (Appendix 1). The formal letter is the only one to repeat the date and give the full address; the memo and the brief messages are careless with the names of senders and receivers. These illustrate - without the need for further comment - that there is no single email genre. Crystal, writes, "The language of asynchronous [situations where participants are not on-line at the same time] messaging is a curious mixture of informal letter and essay, of spoken monologue and dialogue" (p.148). The more casual the interaction becomes the more it veers towards having characteristics of spoken language.

In spoken conversation intonation, pause and body language are used to indicate a variety of things. On the internet these oral language resources are not available. Crystal notes that to supply the lack of sound and gesture, prosody and paralanguage are remade into CAPS (for shouting), S PA C IN $\mathrm{G}$ (for slowed production) or asterisks for *emphasis* (p.35). Smilies, or emoticons, are used to indicate emotion (:) (2) (pp.36-7).

In face-to-face conversation turn taking is organzied cooperatively using intonation, pause and body language to indicate when a person is ready to stop or start speaking. In synchronous messaging [where participants communicate in real time] although all parties are present at the same time they are not able to use these techniques to control topic and turn-taking. Crystal claims, "As with asynchronous groups, the notion of turn-taking and its associated concepts (such as interruption) is once again undermined" (p.152). This claim is made on the basis that a message can't be sent at the same time as it is being uttered as in speech. To the writer the turn begins when they type the first symbol, but to the readers the turn does not start until the complete message appears on the screen, by which time messages from other participants may have arrived. Crystal notes that, because of this lag, people are under pressure to keep their messages short (p.156). It also explains why they often hit return several times during one message.

Chat room text is the most transient of all forms of electronic communication. There is an example of chat room text in Appendix Two. This extract starts with a discussion of musical tastes and opera and moves into a disjointed discussion of "where are the girls" and personal identity. "ID" is expressed as "asl" (age/sex/location) on the internet. In this "conversation" we find that Aaa and Ddd are both from The Phillipines, but Ddd is in New Zealand; Www and Aaa are both close to the town of Bristol in Virginia, USA. They appear to be students (there are references to "studying" and going to "school"). $\mathrm{Jjj}$ is looking for girls and kisses and is quite disruptive; he leaves after expressing boredom. Hhh makes a single plea to visit a particular web site and "try to change the world" (presumably they move on to other chat rooms to make the same plea). Besides asl, two common internet expressions of feeling, lol (laugh out loud) and a smiley face freisalsenger (2001) says chat is "the most innovative form of computer mediated communication due to the fact that they [sic] operate almost synchronously". Crystal, and those he quotes, express surprise that participants tolerate the disruptions of topic and turn taking involved.

People don't go to chat rooms for information; "The atmosphere, even when a topic is in sharp focus, is predominantly recreational. . . Language play is routine. Participants frequently provide each other with expressions of rapport ...". It would seem that, when the social advantages are so great, people make enormous semantic allowances. Several authors make the point that the presence of linguistic confusion and incoherence could be inherently attractive, because the social and personal gains - of participating in an anonymous, dynamic, transient, experimental, unpredictable world - are so great (Crystal, 2001:169). 
Coghlan (2001) deals with emails, forums, and chat, and wonders how to moderate (control) them; he finds that he can't! I would prefer to suggest that new interactive norms develop, that young users adapt themselves to these very quickly and that chat rooms used by older chatters move more slowly and show fewer discoursal "innovations". Whilst it is obvious to all commentators that the www will continue to grow and the amount of computer-mediated communication will grow likewise, the future nature of its discoursal features is less clear. While a distinctive variety of language has emerged, it has not settled down, nor will it while new technologies are being developed at such a rate. "Immediate innovation is anticipated in each of the three traditional domains of communication: production, transmission, and reception" (Crystal, 2001:225).

Use of the internet gives added force to my metaphor of the postmodern horizontal layering of language use. In this horizontal layering we can find both old and new varieties of English. In the top layers scientific, technical and commercial functions dominate. Papers published on the web follow the norms of International Academic English. In the middle layers the language begins to move away from traditional standard forms. In even lower strata more interpersonal functions occur and, at the same time, more local sources are deployed. New cultural norms of English language use are being developed with a much wider acceptance of local varieties of English and the mixing of other languages.

English teachers concluded many years ago that we can no longer teach a single standard. Our students need a very broad-based receptive competence to understand, in both written and spoken modes, all the varieties they will encounter. The development of e-language means that they will encounter even more varieties. This raises the question of competing notions of correctness in different target varieties, ie what should be counted as errors. The range of what is acceptable is widening and as a result the notion of correctness needs to be rethought. As we become more and more used to dealing with "netspeak" we will become more and more tolerant of usage that we once would have labeled as errors.

E-speak is being built by many people with good command of standard varieties of English; it is also being built by people with imperfect command and there is no moderation. There will be "errors". There will be various sorts of stripping down in terms of grammar, a simplification. There will continue to be many innovations in lexis. My own best prediction is that a widespread core of English, intelligible to speakers of all the major dialects will develop in addition to the varieties used by various speech communities. It will also be developed by, and contributed to, non-native speakers. Its "home" will be on the worldwide web, but it will be used in face-to-face communication also. It will have a reduced lexis. Areas of grammatical complexity (eg modality/modulation, complex tenses) will simplify considerably.

Is this language use in a cultural vacuum? No, it is not. It is language in a world where culture and cultures are changing dramatically. Is culture some sort of optional extra? No, it cannot be an optional extra; new language and new culture go hand in hand.

\section{TEACHING IMPLICATIONS}

The chief aim of this paper has been to show that our cultural assumptions about the teaching of English as a Foreign Language have to be revised in response to the development of the worldwide web and the language used there. Standard forms of expression and usage are changing and new translocal forms are developing. As language and culture both change so must language teaching.

The implications seem to me to point, not to a need to start with a change in methods of teaching but with a change in cultural focus. Changes in focus will lead to changes in methods, but to start with methods is to put the cart before the horse. There must be an embracing of new technology and an exploration of all its resources, less as a means of teaching the old familiar materials but as a resource for exploring and teaching new genres and new modes, for exploring new transnational cultures and for contributing to their development. Every user of the internet is also a contributor. We and our students are all contributing to the building of a new culture every time we log on.

Maley's concern may have been overemphasized, but his message is important: in a world of competing post-modern discourses it is important to be critical and to make our students be critical. It is important to be able to chart one's own way. He advises teachers to choose "texts which convey the values of cultures other than the consumerist culture ... [to] focus on the weakness and the undesirable effects of the ruling paradigm [and to] reveal the agenda of Consumerism" (Malay, 1996:6-7). He recommends activities 
which are "based on developing the capacity of students to ask the right questions" (p.7). Becoming able to ask the right questions is becoming critical.

So in conclusion I offer twelve suggestions to guide our thinking about EFL and culture in a globalized world:

1. The teaching of high culture can be abandoned.

2. Teaching about everyday cultures can be cut back.

3. Familiar notions of situational context are less useful to teachers than they once were.

4. Notions of the defining differences between spoken and written language will need to be revised.

5. Advanced students will continue to benefit from traditional EAP/ESP for reading conventional academic and technical documents on the web.

6. Teachers should use texts from electronic sources, even if their English appears to violate accepted norms.

7. We must teach web literacy.

8. We should discuss web pages with students as cultural documents and critique with them the values they represent.

9. We have to develop, and encourage, flexibility towards new genres and new modes of language use.

10. We should exploit our learners' online interests wherever they lead (and follow them there)

11. At all times we should encourage students not to take things at face value, and to be critical of the values represented in the texts they read.

12. We should encourage our students to see themselves as participants in the web, and as creators of its culture.

\section{REFERENCES}

ALB. 1999. "A Capitalist Criticinen Capitalism" Socialist Standard April 1999. Retrieved 31" July, 2004 flom http://www. worldsocialism.org/soros.htm.

Arnold, M. (1869). Culture and Anarchy, Edited with an Introduction by J. Dover Wilson, 1960. London: CUP

Beishwenger, M. (2001), Chat-Kommunikation. Retrieved $22^{\text {nd }}$ September, 2004 from http://www. chat-kommunikation.de/chat2001/intro-en.html.

Cisler, S. (2000). Subtract the Dieital Divide. Online Essay. Retrieved 7 July, 2003 from http:/home inreach.com/cisler/divide.htm.

Coghlan, M. (2001). eMODIRA IION - Managing a New Language? Paper Presented at the $\mathrm{Net}^{*}$ Working 2001 Conference - from Virtual to Reality, Brisbane, October 2001. Retrieved $22^{\text {nd }}$ September, 2004 from http://users.chariot net.au/ michaclc/nw2001/emod newlang.htm.

Crystal, D. (2001). Language and the Internet. Cambridge: CUP

Das, S.K. (1982). Indian English. In J.B. Pride (ed.), New Englishes. Rowley: Newbury House

Garofalo, R. (1993). Whose World, What Beat: The Transnational Music Industry, Identity, and Cultural Imperialism. The World of Music, 35 (2), $16-22$.

Global English: World English Dictionaries. Retrieved $2^{\text {nd }}$ November, 2004 from http://www.askoxford.com/globalenglish/dictionaries/?view=uk.

Geertz, C. (1973). The Interpretation of Cultures. New York: Basic Books.

Globalisation Guide.org (2002). "What is Globalisation?" Retrieved $31^{\text {st July }}$ 2004 from http://www.globalisationguide.org/01 html.

Graddol, D. (1997). The Future of English? A Guide to Forecasting the Popularity of the English Language in the $21^{s t}$ Century. London: British Council.

Halliday, M.A.K. (1978). Language as Social Semiotic. London: Edward Arnold.

Hoggart, R. (1957). The Uses of Literacy. Harmondsworth: Penguin Books.

Holliday, A. (1994a). Appropriate Methodology and Social Context. Cambridge: CUP.

Holliday, A. (1994b). Student Culture and English Language Education: An international perspective. Language, Culture and Curriculum, 7 (2) $125-143$. 
Hunter, D.E., and P. Whitten. (1977). The Study of Cultural Anthropology. New York: Harper And Row.

IPS-Inter Press Service. 2004. Asia: Globalization Erodes Local Languages, Fuels "Glocal" English. Retrieved $21^{\text {st }}$ July, 2004 from http://www. ipsnews.net/print.asp?idnews $=19458$.

Kachru, B.(1988). The Sacred Cows of English. English Today, 16, 3-8,

Klages, M. (2003). Postmodernism. Retrieved $29^{\text {th }}$ July 2004 from http://www.colorado.edu/English/ENGL201Klages/pomo.html.

Kramsch, C. (1993). Context and Culture in Language Teaching. Oxford: OUP.

Kumar, K. (1997). The Post-Modern Condition. In A.H. Halsey, H. Lauder, P. Brown and A.S. Wells (Eds.), Education:Culture, Economy, and Society. Oxford: OUP.

Lee, A. and C. Poynton. (2000). Culture, Text and Context. St Leondards, NSW: Allen and Unwin.

Liddicoat, A.J., and C. Crozet. (1997). Teaching Language Teaching Culture. Australian Review of Applied Linguistics. Series S, 14. $1 \mathrm{ff}$.

Maley, A. 1996). The Empire of McDonald Duck. In J.E. James (ed.), The Language-Culture Connection. Anthology Series 37. Singapore: SEAMEO Regional Language Centre, 1-8.

Oxford English Dictionary. Retrieved $2^{\text {nd }}$ November from http://dictionary. oed.com/

Phillipson, R. (1992). Linguistic Imperialism. Oxford: OUP.

Phillipson, R. (2001). Global English and Local Language Policies: What Denmark Needs. Language Problems and Language Planning, 25, 1, 1 24. [Inaugural Lecture, Department of English, Copenhagen Business School $6^{\text {th }}$ October, 2000.]

Sociology at Hewett... (nd). Retrieved $29^{\text {th }}$ July 2004 from http://www. hewett.norfolk.sch.uk/curric/soc/POSTMODE/key.htm.

Stromquist, N.P. (2002). Education in a Globalized World: The Connectivity of Economic Power, Technology, and Knowledg. New York: Rowman and Littlefield.

Taylor, P. (2004). Cultural Imperialism? British Council. Retrieved $13^{\text {th }}$ October, 2004 from http://www.britishcouncil.org/history/historywhy/istory-why-cultural-imperialism.htm.

Tripathi, P.D. (1998). Redefining Kachru's 'Outer Circle' of English. English Today, 56 (4), 55-58.
Warschauer, M. (2003). Dissecting the "Digital Divide": A Case Study in Egypt. The Information Society, 19, 297-304.

White, LA. (2000). Reconsidering Cultural Imperialism Theory. TBS Achieves, 6. Retrieved $15^{\text {th }}$ August, 2004 from http://www.tbsjournal. com/rchives/Spring01/white.html.

Yamaguchi, C. (2002). "Towards International English in EFL Classrooms

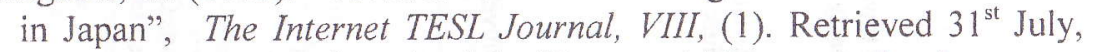
2004 from http://itesli.org/Articles/Yamaguchi-Language.html 


\section{Appendix One}

\section{EMAIL: PROFESSIONAL LETTER}

From : alip@staff.usd.ac.id

Date: Wednesday, 20 October 2004 1:30 PM

To : Dr. Gillian Perrett

Subject : Re: visit to USD

Yogyakarta, October 20, 2004

Dr. Gillian Perre

Dept English Language and Applied Linguistics

University Brunei Darussalam

Dear Dr. Perrett,

It is our pleasure to invite you to the 9th English in South East Asia Conference which will be held on

Days/Dates: Monday to Wednesday, 13 to 15 October 2004

Venue . : The 3rd Floor, Library Building, Campus II, Sanata Dharma University.

The Committee has delightfully decided to accept your abstract for your presentation in the conference. If you wish your complete paper to appear in the Conference Proceedings (with an ISBN serial number), we expect to receive it no later than 16 November 2004 in the form of a file attachment sent to our email address.
If you are not a resident of Indonesia, for your travel convenience, please consult the local office of the Indonesian Embassy for visa advice before your departure to Indonesia

Sanata Dharma will be very glad if your could visit us on October 10,2004 to discuss issues in EAP as well as "Fiction of Mulk Raj Anand". We are looking forward to seeing in Yogyakarta.

Sincerely yours,

Dr. Francis Borgias Alip, M.Pd., M.A.

Chair: The 9th ESEA Conference Committee

(Dean of Faculty of Letters, Sanata Dharma University)

\section{EMAIL: OFFICE MEMO}

From : Hj. Matamit Ratu

Date: Thursday, 9 September 2004 5:10 AM

To: staff

Subject : Using of Sports Complex

Please be informed that the Sports Hall of Sports Complex will be shut at 5.00 pm every Monday. This is due to the facility is used for teaching purposes.

I regret for inconveniences

\section{EMAIL: PERSONAL LETTER}

From: dave packham davepackham $(a$ hotmail com

Date: Thursday 13, May, 20049.47 AM

To: gillianperrett@brunet.bn

Subject: holiday

Hi mum,

How are you? Hope that you are having a good time. I am so looking forward to comming and seeing how you have settled in. You had been there such a short time at the point of my last visit it will be fun to see how things have progressed for you.

I am feeling really busy. I got some good marks for my first lot of assessments at uni. A $\mathrm{D}$ for my mid semester economics exam and a D for my first Marketing assingment. To achieve this I worked very consistently but never really felt any pressure. The next to follow was my Marketing mid semester. After kicking off with a D I felt some pressure to maintain this level. I did lots of work and went into the exam feeling confident that I knew the material that was to examined. The nerves did kick in a little when they said "commence writing" and I did find the format of the exam challenging. It had been four years since I have attempted that kind af assessment. We had to write six essays of two pages each in two hours. That meant 20 min a question and through discussing some practice questions in our tutes I knew what was expected. At least two pages of structured critical annalysis. Despite feeling confident this was a challenge and the nerves did not help. I think I wrote four really good answers, mis read a question in a rush and possibly wrote a comlete dog and was pushed for time in the last and wrote an average answer. I left the exam feeling fine about it all. I thought I had easily passed and that it was all practice and id do heaps better in the future with a similar level of effor put into preperation. I had a chance to read the paper again yesterday and for the one mucked up - it was a difficult question but I simply did not take the time to relax and read the question properly. It was managable but with the pressure of the whole $20 \mathrm{~min}$. two pages thing I chose to attempt a simpler question I had not properly prepared for There was plenty of scope to do practice questions before the exam and have them marked by your tutor but I felt I did not have time to do this. Results for the exam are out in four days so it will be intersting to see how I went.
I have managed to maintin some sort of social life (well a pretty good one) but I might try and focus on uni for the next little bit. Not long to go and I get a beaut holiday at the end of it. It is a real shame that I am sacrificing my surfing and my trips to waggy for the sake of studying however. Surfing is still the focus of my life and I am regularly giving it a miss to study. Only getting in the water twice a week in the last four weeks. And waggy - I don't need to explian what I am missing there. I will plan one study/surfing/maintenance waggy trip before my holiday - well maybe two. Have to see how it pans out

I would love to speak to you on the phone but I cant get a phone card until I get paid on 19.05. I'll call shortly after. This pay I bought a $\$ 300$ surf board bag for my super surfin get away. Being short is OK with all that in mind

Ok mum, love you, talk soon, be well and let me know when you want me and give suggetions as to the cheapest best way to go Brunei - bali - sydhey Vs bali - brunei - bo -sydney etc etc. I am thinking of being more adventurous this time so a longer stretch in indo would be good. Want to fly from bali to west timor and hed back to bali overland sounds good hey.

Ok

Bye Bye - love you

Dave

EMAIL: A CASUAL NOTE

From: dave packham davepackham ahotmail cont

Date: Thursday 27, May, 200410.22 AM

To: gillianpertett abrunet bn

Subject: RE: URGENT

Hi mum,

Got money, don't hurry re the dennissy. I am ner going is of anything dime unil I am

finished with this study. So not for nwo wedis

Thanks

love you Dave 
From: Gillian Perrett < gperrett@brunet.bn> To: Robert Bush <robert@yahoo.com> Subject: Re: Hello from Ranau . Izumi \& Jim Date: Sun, 10 Oct 2004 17:12:36+0800

Dinner Thurs? Bowling Club? G.
From: Robert Bush<robert@hotmail.com>

To: Gillian Perrett <gperrett@brunet.bn>

Subject: Re: Hello from Ranau . Izumi \& Jim

Date: Sun, 10 Oct 2004 8.50 PM

excellent Idea. Its in the diary. $\mathrm{R}$

\section{Appendix Two}

\section{CHAT ROOM}

ddd what kina muso do you like?

\section{kkk OPERA}

kkk and lots of other stuff

jjj hey friend kiss

ddd what kina muso do you like?

ddd heh operasux

hhh watch this url nd listen wat ur heart

says...nd try to change this world..., pls http:digitaljournalist.org/issue0212/pt01. html

jjj Ineed akiss

ddd what kina muso do you like?

aaa I'm $24 \mathrm{~m}$ Philippines

ddd mez

bbb hey room

kkk you suck too? Is that what you said?

jjj man where are the college gurls kkk just because you don't like opera you should degrade yourself

aaa I'm $24 \mathrm{~m}$ Philippines!

jjj where are the college gurls

jjj

ddd

jij arn why don't you go to a Philip chat room

hey me2

gurl

hello

wow

hu is a gur

man I guess the gurls are really studying

today

heh get over it man

Hey everyone!!!!!

hey all

yea or stuck in bed?

how's everyone tonight???

hey www

Hey John!

$22 / \mathrm{m} /$ va here... Virginia ech, Blacksburg

hey sss

wow

\begin{tabular}{|c|c|}
\hline www & How are you all tonight?? \\
\hline www & I'mn from Virginia !!! : ) \\
\hline jjj & hey miss \\
\hline ddd & I am fine urself? \\
\hline jjj & me too \\
\hline III & hey miss \\
\hline www & hoy lover ... |ol \\
\hline jjj & what so funny \\
\hline www & lol ... hmmmn.... yes \\
\hline ddd & WELL \\
\hline sss & what part of va miss wwom? \\
\hline ddd & well \\
\hline wwW & do you know a lot of maie musue i= \\
\hline wWw & close to Bristoll \\
\hline jjj & damn! I got to get a kn= \\
\hline WWW & Bristol sorry \\
\hline ddd & there is a lot here tring \\
\hline SSS & north of it? \\
\hline sSS & I'm like 1.5 hourss nom \\
\hline$Z Z Z$ & hi \\
\hline$d d$ & 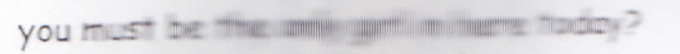 \\
\hline
\end{tabular}




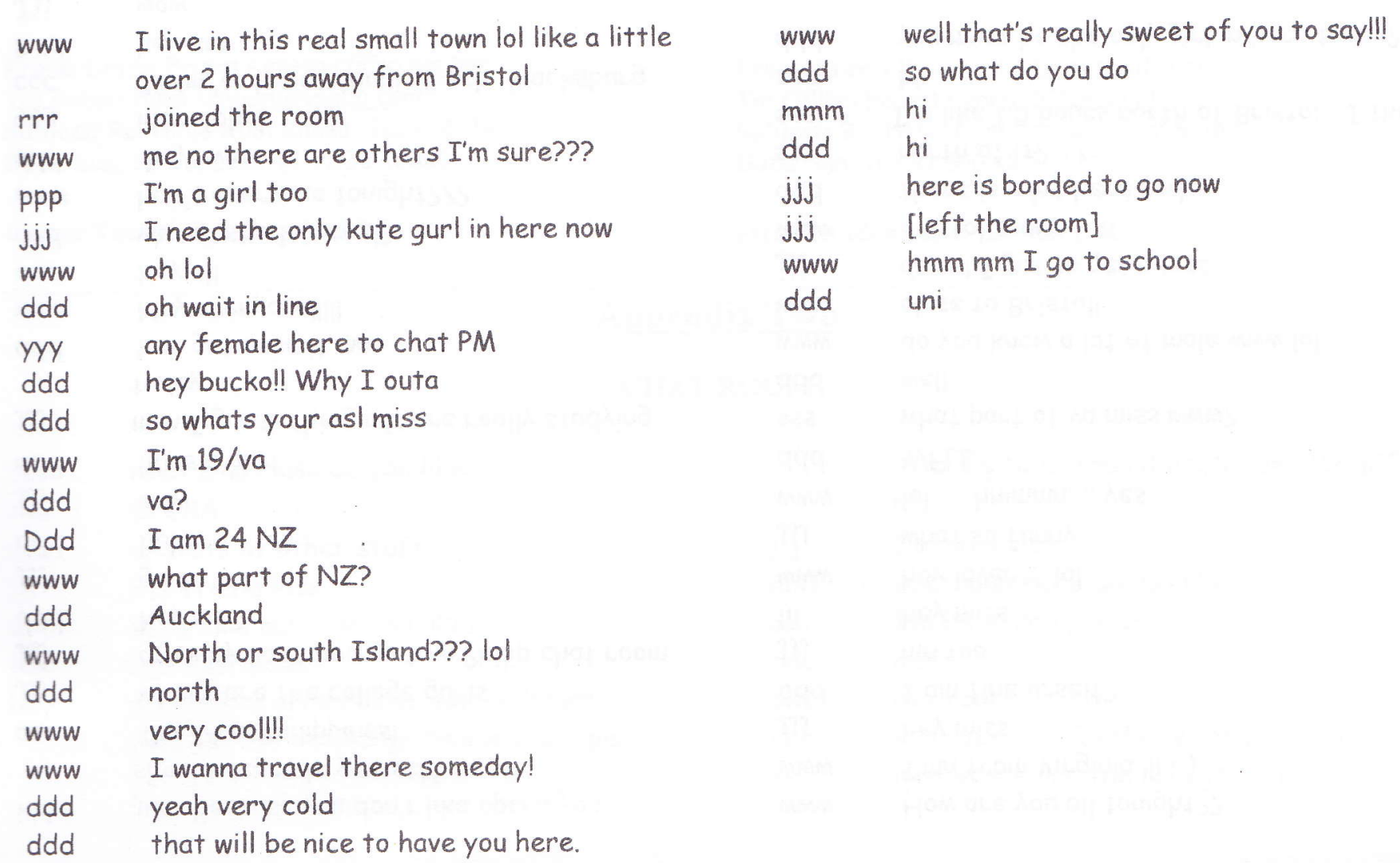

